\title{
Fatty Acid, Total Phenol and Tocopherol Profiles of Some Walnut Cultivars: A Comparative Study
}

\section{Ebru Kafkas' ${ }^{1}$ Aysegul Burgut ${ }^{1}$, Hatice Ozcan², Akide Ozcan², Mehmet Sutyemez ${ }^{2}$, Salih Kafkas' , Nurgül Türemis ${ }^{*}$}

${ }^{1}$ Department of Horticulture, Faculty of Agriculture, University of Çukurova, Adana, Turkey

${ }^{2}$ Department of Horticulture, Faculty of Agriculture, University of Sütçü İmam, K. Maraş, Turkey

Email: htc_zcn@hotmail.com, aburgut@gmail.com,ozcanakide@gmail.com, sutyemezmehmet@gmail.com, salihkafkas@gmail.com, ^nturemis@gmail.com, *ebruyasakafkas@gmail.com

How to cite this paper: Kafkas, E., Burgut, A., Ozcan, H., Ozcan, A., Sutyemez, M., Kafkas, S. and Türemis, N. (2017) Fatty Acid, Total Phenol and Tocopherol Profiles of Some Walnut Cultivars: A Comparative Study. Food and Nutrition Sciences, 8, 1074-1084.

https://doi.org/10.4236/fns.2017.812079

Received: October 13, 2017

Accepted: December 3, 2017

Published: December 6, 2017

Copyright $(9) 2017$ by authors and Scientific Research Publishing Inc. This work is licensed under the Creative Commons Attribution International License (CC BY 4.0).

http://creativecommons.org/licenses/by/4.0/

\begin{abstract}
As a member of nuts, walnut is consumed from snacks to salads and desserts to entrees and an importantpart of human diet for centuries. Walnut biological and nutritional value is also enhanced by its valuable protein and rich in nutrient composition such as vitamins and minerals. The most important characteristic of walnut oil is the abundance of polyunsaturated fatty acids, which makes it a unique food because of high amount of linoleic acid. Due to having valuable protein, vitamins and minerals it enhances biological and nourishment value, also. Recent epidemiological studies showed that consumption of walnut reduce cardiovascular diseases due to the rich in antioxidant properties, valuable fatty acids and tochopherols contents. In Turkey, walnut production and consumption increases year by year. The kernel of walnut genotypes shows variability in terms of their fat, fatty acid and tocopherol profiles. In this paper, it was aimed to characterize 10 walnut (Juglans regia L.) cultivars (Bilecik, Chandler, Hartley, Howard, Maraş 12, Maraş 18, Midland, Pedro, Şen and Serr) based on their fatty acid profiles using GC (Gas Chromatography), tocopherol and its isomers by HPLC (High Performance Liquid Chromatography) and total phenol content with spectrometric methods. Among the walnut cultivars "Hartley" was the highest linoleic acid (64.56\%) and "Howard" was the $\alpha$-linolenic acid 13.26 (\%). The highest values of $\alpha(38.76 \mu \mathrm{g} / \mathrm{g}), \beta+\gamma(312.19 \mu \mathrm{g} / \mathrm{g})$ and $\delta$-tocopherol $(40.77 \mu \mathrm{g} / \mathrm{g})$ and total phenol (349 mg GAE/100 g ext) content were detected in "Sen" cultivar. Obtained results might be significant for further breeding programme to im-
\end{abstract}


prove rich in especially $\gamma$-tocopherol linoleic acids and total phenolic compounds.

\section{Keywords}

Fatty Acid, GC, HPLC, Juglans regia L., Tocopherols, Walnut

\section{Introduction}

As a member of Juglandaceae family, walnut (Juglans regia L.) is also known as an English or Persian walnut, one of the oldest cultivated nut in the world and grown universally everywhere almost in all geographical regions in Turkey [1] [2]. Juglans regia L., is economically cultivated everywhere especially in the temperate regions of the world. There is a report that walnut is possibly originated from the Iran-Afghanistan places and later introduced to Eastern Europe, China and Russia regions. There is another report on history of walnut cultivation grown Mediterranean region [3]. Anatolia is also known one of the native countries for Persian walnut, also [4]. Recently, average year of walnut production in Turkey approximately has reached 212.000 tons [5]. Walnut consumption trend increases year by year due to the scientific reports on health benefits especially loosen the risk of cardiovascular diseases [6] [7]. Walnuts are also important due to the rich in antioxidant properties which loosen the risk of many diseases by reduction of oxidation process [8] [9] [10] and a source of essential fatty acids and tocopherols [11] [12]. There are also previously published reports on antimicrobial distinctiveness of walnut [13].

Walnuts are highly enriched in health related compounds such as polyunsaturated fatty acids, fiber, copper, magnesium, and vitamin $\mathrm{E}$ and mostly consist of monounsaturated (MUFA's) and polyunsaturated fatty acids (PUFA's) which positively influence serum lipids. According to clinical and epidemiological reports omega-3 (PUFA's) might have a significant role in the prevention CHD (Coronary Heart Disease) and play antiarrhythmic, antithrombotic, and hypolipidemic roles [14] [15]. Abbey et al., [16] reported that daily intake $68 \mathrm{~g}$ of walnuts per day reduced the total and low-density lipoprotein cholesterol by 5 and $9 \%$, respectively; this act reduced the risk of coronary heart diseases. Few studies previously reported on some fruit quality properties such as fatty acid, total phenol and tocopherol contents of walnuts growing in Turkey [17] [18] [19] [2]. There are a few reports previously published related to fat, fatty acid and tocopherol characteristics of walnut in temperate zone regions of Turkey. However, no detailed study has so far been previously published on fat, fatty acid, total phenol and tocopherol content of commercially grown walnut cultivars in the Mediterranean region of Turkey. The purpose of this study was to compare ten walnut cultivars based on their fat, fatty acid, total phenol and tocopherol profiles using spectrophotometric and chromatographic technique. 


\section{Materıals and Methods}

\subsection{Experimental Materials}

Commercially ripen stages of walnut cultivars were harvested from Research and Experimental Implementation area of University of Çukurova, Faculty of Agriculture, located in the Adana provinces of Mediterranean region of Turkey in November, 2015. Harvesting were done when the husk changes from solid green to yellowish green. Foreign and local cultivars were used due to the comparing their kernel characteristics in Asana ecological conditions. In the experiment, 9 trees were selected for each genotyp and 25 walnut fruits were randomly harvested from each trees. Triplicate analysis were done using randomly selected walnut and each replicate 75 randomly selected walnut fruits were used. Kernel of walnut fruits were analyzed after drying using incubator.

\subsection{0il Extraction}

Walnut fruits were separated their kernel using nutcracker and after the separation immediately homogenized and oil extraction of kernel powder (25 g) were done using automatic Soxhalet equipment Bligh and Dyer [20]. Automatic Soxhlet equipment (Gerhardt Soxtherm) was used for oil extraction with hexane organic solvent. Triplicate analysis were done for each variety. Methylation were done using Boron trifluoride/methanol [21] [22].

\subsection{Fatty Acid Analyses}

Fatty acid analysis were done using a GC (Gas Chromatography)/FID (Flame Ionization Detector) (Perkin Elmer, Clarus 500, USA) equipped with a and SGE column $(100 \mathrm{~m} \times 0.32 \mathrm{~mm}$, ID $0.25 \mu \mathrm{m})$. As fort he GC condition; the oven temperature was held at $140^{\circ} \mathrm{C}$ for $5 \mathrm{~min}$, and then increased to $200^{\circ} \mathrm{C}$ at a rate of $4^{\circ} \mathrm{C} \mathrm{min}{ }^{-1}$ and to $220^{\circ} \mathrm{C}$ at a rate of $1^{\circ} \mathrm{C} \mathrm{min}{ }^{-1}$. FAME mix standard including 37 component were used for fatty acid identification and quantification.

\subsection{Tocopherol Analyses}

Tocopherol analysis were done using $1 \mathrm{~g}$ of oil. Analyses of tocopherol isomers such as $\alpha$-tocopherol, $B$ and $\gamma$ tocopherol and $\delta$ tocopherol were performed by HPLC technique according to developed method by Surai et al., [23] and Surai, [24]. $3 \mu \mathrm{m}$ RP-C18 reverse phase Spherisorb ODS2 column, $(15 \mathrm{~cm} \times 4.6 \mathrm{~mm})$ and methanol/water $(97: 3 \mathrm{v} / \mathrm{v} ; 1.05 \mathrm{ml} / \mathrm{min})$ was used as mobile phase Calibration were done using external standards of tocopherol isomers. Excitation 325 $\mathrm{nm}$ and emission $490 \mathrm{~nm}$ in the first 5 minutes were followed by excitation 295 $\mathrm{nm}$ and emission $330 \mathrm{~nm}$ with Fluorescence Detector [23] [24].

\subsection{Total Phenolic Content Analysis}

Total phenolic content of walnut genotypes were done by modifying spectrophotometric Folin-Ciocalteu's method developed by Spanos and Wrolstad [25] and $10 \mathrm{ml}$ of methanolic extract for $1 \mathrm{~g}$ homogenized walnut kernel were used. 
Obtained values expressed as mg gallic acid equivalent in $100 \mathrm{~g}$ extract (mgGAE/ 100gext).

\subsection{Statistical Analyses}

Triplicate GC/FID, HPLC and spectrometric analyses were performed and a completely randomized design using analysis of one-way analysis of variance (ANOVA).

\section{Results and Discussions}

The results of $\alpha, \beta+\gamma$ and $\delta$-tocopherol content of various walnut (Juglans regia L.) cultivars (Bilecik, Chandler, Harley, Howard, Maraş 12, Maraş 18, Midland, Pedro, Şen and Serr) grown in Adana region of Turkey were shown in Table 1. As seen in Table 1, tocopherol and its isomers such as $\alpha, \gamma+\beta$, and $\delta$ tocopherol content of experimental walnut varieties were differed. $\alpha$-tocopherol content of cultivars varied between $28.33 \mu \mathrm{g} / \mathrm{g}$ (Howard) to $38.76 \mu \mathrm{g} / \mathrm{g}$ (Sen), $\beta+\gamma$ tocopherol content varied between $161.01 \mu \mathrm{g} / \mathrm{g}$ (Howard) to $312.19 \mu \mathrm{g} / \mathrm{g}$ (Sen) and as for the $\delta$-tocopherol content varied between $17.35 \mu \mathrm{g} / \mathrm{g}$ (Serr) to $40.77 \mu \mathrm{g} / \mathrm{g}$ (Sen) oil (Table 1). The lowest $\alpha, \beta+\gamma$ tocopherol content was detected in "Howard" walnut cultivar while the highest in Sen cultivar. According to the previous reports, $\gamma$ tocopherol content of walnut was about $25 \mathrm{mg} / 100 \mathrm{~g}$ in kernel oil and as major tocopherol isomer whereas $\beta$ and $\alpha$-tocopherol are about $1-5 \mathrm{mg} / 100 \mathrm{~g}$ [26]. In another previous study, $\gamma$ tocopherol was detected as the highest tocopherol isomer while $\alpha$-tocopherol was the lowest and approximately 6\% [27]. In another study, the highest content of the tocopherol isomers in the kernel oil was determined as $\gamma+\beta$ tocopherol and $\gamma$-tocopherol has been reported to be much more powerful than $\alpha$-tocopherol in detoxifying lipophilic electrophiles [28]. Amaral et al. reported that [11], the tocopherol content of walnut (Juglans regia L.) cultivars such as Mayette, Arco, Franquette, Lara, Marbot, Hartley,

Table 1. Tocophorels and its isomers and total phenolic contents of various walnut varieties.

\begin{tabular}{ccccc}
\hline Varieties & $\begin{array}{c}\alpha \text {-tocopherol } \\
\mu \mathrm{g} / \mathrm{g}\end{array}$ & $\begin{array}{c}\gamma \text {-tocopherol }+B \\
\text { tocopherol } \mu \mathrm{g} / \mathrm{g}\end{array}$ & $\begin{array}{c}\delta \text {-tocopherol } \\
\mu \mathrm{g} / \mathrm{g}\end{array}$ & $\begin{array}{c}\text { Total Phenol } \\
\text { mgGAE/100 gext }\end{array}$ \\
\hline Bilecik & $32.65 \pm 0.452$ & $247.51 \pm 10.649$ & $25.15 \pm 0.883$ & $3170 \pm 3.8$ \\
Chandler & $35.17 \pm 2.213$ & $254.18 \pm 24.048$ & $24.24 \pm 2.552$ & $2650 \pm 1.9$ \\
Hartley & $30.78 \pm 1.131$ & $266.38 \pm 11.377$ & $27.49 \pm 0.615$ & $2680 \pm 1.0$ \\
Howard & $28.33 \pm 0.848$ & $161.07 \pm 7.488$ & $23.89 \pm 5,706$ & $2530 \pm 4.1$ \\
Maras 12 & $34.46 \pm 2.177$ & $236.13 \pm 12.183$ & $29.32 \pm 1.541$ & $2440 \pm 1.3$ \\
Maras 18 & $28.61 \pm 0.381$ & $230.70 \pm 7.318$ & $28.56 \pm 1.555$ & $2840 \pm 1.9$ \\
Midland & $29.43 \pm 1.0394$ & $235.48 \pm 1.675$ & $25.57 \pm 0.438$ & $3170 \pm 3.8$ \\
Pedro & $28.66 \pm 0.077$ & $226.44 \pm 7.219$ & $21.67 \pm 0.593$ & $2370 \pm 1.1$ \\
Sen & $38.76 \pm 1.230$ & $312.19 \pm 11.455$ & $40.77 \pm 1.378$ & $3490 \pm 4.9$ \\
Serr & $31.48 \pm 1.626$ & $191.44 \pm 7.014$ & $17.35 \pm 0.523$ & $2650 \pm 3.6$ \\
\hline
\end{tabular}


Mellanaise, Parisienne, and Reg were compared and $\gamma$-tocopherol was the most abundant tocopherol isomer in all cultivars. The same authors reported that environmental factors play an important role oil tocopherol profile.

The total phenolic content of walnut cultivars varied between $2440 \mathrm{mgGAE} /$ $100 \mathrm{~g}$ ext to $3490 \mathrm{mgGAE} / 100 \mathrm{~g}$ ext (Table 1 ). As reported previous studies the average value of total phenolics is lowest in pines (32) while highest in walnuts (1625) mg GAE/100 $\mathrm{g}$ which is in accordance with previously published data [29] and [30]. In another study, Abe et al. [31] reported that total phenolic content of nuts was highly variable and ranged from $50 \mathrm{mg} 100 \mathrm{~g}^{-1}$ (FW) (Pinhao seeds raw ) to $2499 \mathrm{mg} 100 \mathrm{~g}^{-1}$ (FW) (Walnut raw). Similar to our study and previous reports, Kornsteiner et al. [32] also reported the highest total phenolic values in walnuts (1020 - $2052 \mathrm{mg} 100 \mathrm{~g}^{-1} \mathrm{FW}$ ) compared to pecans (1022 - 1444 $\mathrm{mg} 100 \mathrm{~g}^{-1} \mathrm{FW}$ ) and pistachios (492 to $1442 \mathrm{mg} 100 \mathrm{~g}^{-1} \mathrm{FW}$ ), respectively.

Total lipid content and fatty acid profile is one of the most significant parameter distinguishing of the walnut cultivars. The results of total lipid and saturated fatty acid profiles of 10 walnut cultivars are given in Table 2. Maraş 18 were the highest lipid content (70.7\%), while Maraş 12 (46.4\%) the lowest. Mitrovic et al., [33] studied eight walnuts varieties and selections (Dorka, Ceinovo, Ibar, Vujan, Ovcar, G-139, G-251 and G-286) and the highest value detected as $68.81 \%$. Similarly, Maraş 18 is the highest lipid content in our research. Savage et al. [27], studied US commercially grown walnut varieties (Tehama and Vina), three European commercial varieties (Esterhazy, G139, G120), and eight New Zealand selections (Rex, Dublin's Glory, Meyric, Stanley, Mckinster, 150, 151, $153)$ in an implementation area at Lincoln University. The same author reported that total lipid content of nuts ranged from $64.2 \%$ to $68.9 \%$. Beceanu et al. [34] implied that generally in walnuts total lipid ranged from $62 \%$ to $65 \%$.

A total saturated fatty acids are not statistically different among varieties

Table 2. Lipid and saturated fatty acid content (\%).

\begin{tabular}{|c|c|c|c|c|c|c|}
\hline \multirow[b]{2}{*}{ Varieties } & \multirow{2}{*}{$\begin{array}{l}\text { Lipid } \\
(\%)\end{array}$} & \multicolumn{5}{|c|}{ Saturated fatty acids (\%) } \\
\hline & & $\begin{array}{c}\text { Myristic } \\
\text { C14:0 }\end{array}$ & $\begin{array}{c}\text { Palmitic } \\
\text { C16:0 }\end{array}$ & $\begin{array}{c}\text { Stearic } \\
\text { C18:0 }\end{array}$ & $\begin{array}{c}\text { Arachidic } \\
\text { C20:0 }\end{array}$ & $\begin{array}{c}\sum \text { Saturated } \\
\text { FA }\end{array}$ \\
\hline Bilecik & $63.0 \pm 2.65$ & $0.019 \pm 0.0029$ & $5.82 \pm 0.421$ & $3.82 \pm 0.491$ & $0.12 \pm 0.098$ & 9.77 \\
\hline Chandler & $62.3 \pm 2.65$ & $0.017 \pm 0.0013$ & $5.92 \pm 0.581$ & $3.41 \pm 0.305$ & $0.10 \pm 0.051$ & 9.44 \\
\hline Hartley & $62.8 \pm 3.25$ & $0.021 \pm 0.0083$ & $6.16 \pm 0.317$ & $3.59 \pm 0.384$ & $0.12 \pm 0.020$ & 9.89 \\
\hline Howard & $64.5 \pm 2.29$ & $0.021 \pm 0.0020$ & $6.13 \pm 0.451$ & $3.44 \pm 0.169$ & $0.12 \pm 0.048$ & 9.71 \\
\hline Maraş-12 & $46.4 \pm 2.23$ & $0.021 \pm 0.0079$ & $6.57 \pm 0.593$ & $3.70 \pm 0.153$ & $0.11 \pm 0.096$ & 10.40 \\
\hline Maraş-18 & $70.7 \pm 3.28$ & $0.022 \pm 0.0071$ & $6.98 \pm 0.353$ & $3.59 \pm 0.279$ & $0.10 \pm 0.091$ & 10.69 \\
\hline Midland & $50.20 \pm 1.58$ & $0.023 \pm 0.0056$ & $6.41 \pm 0.553$ & $3.86 \pm 0.331$ & $0.11 \pm 0.082$ & 10.41 \\
\hline Pedro & $65.9 \pm 2.89$ & $0.021 \pm 0.0020$ & $6.72 \pm 0.612$ & $3.97 \pm 0.435$ & $0.13 \pm 0.066$ & 10.84 \\
\hline Şen & $49.4 \pm 1.48$ & $0.029 \pm 0.0019$ & $6.58 \pm 0.577$ & $3.23 \pm 0.183$ & $0.11 \pm 0.037$ & 9.94 \\
\hline Serr & $62.0 \pm 2.25$ & $0.021 \pm 0.0020$ & $6.57 \pm 0.593$ & $3.88 \pm 0.260$ & $0.10 \pm 0.052$ & 10.57 \\
\hline
\end{tabular}


(Table 2). As seen in Table 2, myristic (C14:0), palmitic (C16:0) stearic (C18:0) arachidic (C18:0) acids were detected as saturated fatty acids and the most abundant saturated fatty acid detected as palmitic acid. Doğan and Akgul [35], detected fatty acid composition of some walnut (Juglans regia L.) cultivars from east Anatolia. In their study, a total oil content of walnut ranged from $65.00 \% \pm$ $0.06 \%$ to $70.00 \% \pm 0.58 \%$. The palmitic acid content of the walnut ranged from $5.61 \%$ to $5.82 \%$ while a trace amount of myristic acid $(<0.1 \%)$ detected in the samples. Popa et al., [36] investigated the saturated and unsaturated fatty acid profile of walnut (Juglans regia L.) kernel oil by GC/MS according to AOAC standards. As a result of that study, palmitic acid (9.75\%) was the major saturated fatty acid, followed by stearic acid (3.48\%). In another study previously reported by Beyazit and Sümbül [37] and the authors investigated fatty acid composition of five cultivars (“Şebin”, "Şen 1", “Tokat 1", "Kaplan 86" \& "KR 2 ") and three genotypes ("Malatya 1", “77H1” \& “65/4") selected form the Eastern Mediterranean region of Turkey. According to their results, palmitic acid values of those genotypes were ranged from $6.98 \%$ to $8.77 \%$, and steraic acid ranged from $3.22 \%$ to $4.99 \%$ in walnut genotypes.

The results of monounsaturated fatty acids and polyunsaturated fatty acids were given in Table 3. Monounsaturated fatty acids (palmitoleic and oleic acid) values varied between $0.11 \%$ to $14.36 \%$ and $0.13 \%$ to $27.57 \%$, respectively. The values are similar to previously published researches when compared to the data in this study. Zwarts et al., [38] reported that two US commercial cultivars (Tehama and Vina), three European commercial cultivars (Esterhazy, 139, G120) and five New Zealand selections (Rex, Dublin's Glory, Meyric, McKinster, and Stanley). The oleic acid content of walnut varieties varied between $12.7 \%$ to $20.4 \%$ of the total fatty acids, while $18: 2$ content varied between $57.0 \%$ to $62.5 \%$ and the $18: 3$ content varied between $10.7 \%$ to $16.2 \%$. Popa et al., [36] reported

Table 3. Unsaturated fatty acid content (\%) of walnut cultivar.

\begin{tabular}{|c|c|c|c|c|}
\hline \multirow{3}{*}{ Varieties } & \multicolumn{4}{|c|}{ Unsaturated fatty acids (\%) } \\
\hline & \multicolumn{2}{|c|}{ Monounsaturated fatty acids } & \multicolumn{2}{|c|}{ Polyunsaturated fatty acids } \\
\hline & Palmitoleic C16:1 & Oleic C18:1 & Linoleic C18:2 & $\alpha$-Linolenic C18:3 \\
\hline Bilecik & $0.10 \pm 0.086$ & $13.80 \pm 0.322$ & $62.92 \pm 0.260$ & $13.16 \pm 0.391$ \\
\hline Chandler & $0.12 \pm 0.021$ & $14.47 \pm 0.173$ & $62.82 \pm 0.204$ & $12.92 \pm 0.735$ \\
\hline Hartley & $0.11 \pm 0.011$ & $12.95 \pm 0.148$ & $64.56 \pm 0.569$ & $12.12 \pm 0458$ \\
\hline Howard & $0.11 \pm 0.091$ & $14.36 \pm 0.510$ & $62.20 \pm 0.581$ & $13.26 \pm 0.805$ \\
\hline Maraş-12 & $0.13 \pm 0.074$ & $21.02 \pm 0.354$ & $59.62 \pm 0.411$ & $8.55 \pm 0.387$ \\
\hline Maraş-18 & $0.13 \pm 0.090$ & $27.57 \pm 0.683$ & $53.42 \pm 0.516$ & $7.83 \pm 0.924$ \\
\hline Midland & $0.12 \pm 0.074$ & $17.63 \pm 0.259$ & $61.22 \pm 0.428$ & $10.33 \pm 0.268$ \\
\hline Pedro & $0.11 \pm 0.070$ & $14.77 \pm 0.112$ & $61.89 \pm 0.164$ & $12.17 \pm 0.420$ \\
\hline Şen & $0.12 \pm 0.087$ & $26.86 \pm 0.916$ & $53.24 \pm 0.433$ & $9.50 \pm 0.574$ \\
\hline Serr & $0.12 \pm 0.067$ & $14.94 \pm 0.201$ & $61.37 \pm 1.540$ & $12.74 \pm 0.903$ \\
\hline
\end{tabular}


the fatty acids composition in saturated and unsaturated of walnut (Juglans regia L) kernel oil that also similar to our study. The same authors detected fatty acid profile by GC-MS according to AOAC standards. Among the detected monounsaturated fatty acids, the oleic acid content of the oil was $13.62 \%$ of the total fatty acid and oleic acid is detected as the most abundant among monounsaturated fatty acids.

Maximum and minimum values of polyunsaturated fatty acids linoleic acid and $\alpha$-linolenic acids are detected as $53.24 \%$ to $64.56 \%$ and $9.50 \%$ to $13.26 \%$, respectively (Table 3). In parallel to previous studies, linoleic acid was the major fatty acid reaching a maximum value of $60.30 \%$ (cv. Lara) followed by oleic, linolenic and palmitic acid which means the fatty acid quantities could be strongly related with the cultivar [39]. Acording to Doğan and Akgül [35], the oleic acid content of the oils ranged from $22.63 \%$ to $27.27 \%$ of the total fatty acids while the linoleic acid and linolenic contents ranged from $49.93 \%$ to $54.41 \%$ and $14.32 \%$ to $17.82 \%$ respectively. The same authors indicated that the fatty acid of walnut cultivars from East Anatolia were distinctive in terms of their linolenic acid profile. Beceanu et al., [34], reported that $44 \%$ - $48 \%$ of the fatty acids in the walnut oil are replaced by polyunsaturated fatty acids and changing in the content of the total fat between $62 \%-65 \%$. In another previos research, linoleic acid content was detected as \%56.57 and linolenic acid 12.09\% in walnut oil [32]. Fatty acid profile was a significant parameter distinguishing the walnut cultivars and genotypes. As a result of this study, linoleic acid ranged from 41.55 to $59.89 \%$ while linolenic acid ranged from $8.44 \%$ to $11.0 \%$. The linolenic acid was detected as the highest. Similar to our results, a study published by Beyazıt and Sümbül [37]. The authors published that "65/4", "KR 2" and "Şebin" genotypes were found to be very promising for oil composition especially fatty acid profiles in the Eastern Mediterranean region of Turkey. The same authors reported that linoleic acid varied between $41.55 \%$ and $59.89 \%$, linolenic acid $8.44 \%$ and $11 \%$ in “Şebin-1", “Tokatşen-1", "Kaplan 86", “Sons”, “KR 2", "Malatya 1", “77H1” 65/4 "walnut genotypes" [33].

The values of SFA, USFA, MUFA and PUFA varied between $9.44 \%$ to $10.84 \%$, $88.95 \%$ to $90.33 \%, 13.06 \%$ to $27.70 \%$ and $61.25 \%$ to $76.74 \%$, respectively. Maraş-18 has the highest MUFA (\%27.7), Bilecik, Chandler and Hartley walnut varieties have similarly high PUFA content (approximately \%76). The PUFA values of the walnut grown in New Zeland found to be relatively similar to our results (64.9 - 76.6). In New Zeland, Zwarts et al. [38], analyzed the fatty acid content of walnut oil obtained with a cold press and reported that the total oil of walnut was ranged between $62.4 \%$ to $68.7 \%$. Acording to another study, the walnut oil contained $21.2 \mathrm{~g} / 100 \mathrm{~g}$ MUFA and $69.0 \mathrm{~g} / 100 \mathrm{~g}$ PUFA [40]. The fruits of "Imshu", "Campbell CW1" (Juglans ailanthifolia) and "Combe" ve "Lake" (Juglans regia L.) varieties were analyzed for their composition in fatty acids and tocopherol. The same researches reported that polyunsaturated fatty acids showed the higher value (\%73 - \%80.98) than the other fatty acids [41]. 
According to the obtained results, Bilecik, Chandler, Hartley, Howard, Maraş 12, Maraş 18, Midland, Pedro, Şen and Serr walnut cultivars have very important values in terms of tocopherols, total phenol, and fat and fatty acids content which are very importance for human health and nutrition. Finally, the fatty acid results indicated that walnut cultivars from East Anatolia were distinctive in terms of their linolenic acid profile. In our study, "Hartley" was the highest both linoleic acid and $\gamma$-tocopherol content (64.56\% and $266.38 \mu \mathrm{g} / \mathrm{g})$, "Howard" has the highest linolenic acid content (13.26\%). Obtained results might be significant for further breeding studies in order to improve higher health related compounds such as $\gamma$-tocopherol and linoleic acids and total phenolic compounds.

\section{Acknowledgements}

Authors thanked to the Çukurova University Scientific Research Project Unit project number FBA-2016-5733 for their financial support.

\section{References}

[1] Şen, S.M. (1986) Ceviz Yetiştiriciliği, Eser Matbaası, 109-229, Samsun-Turkey.

[2] Ozkan, G. and Koyuncu, M.A. (2005) Physical and Chemical Comparision of Some Walnut (Juglans regia L.) Genotypes Grown in Turkey. Grasas y Aceites, 56, 142. https://doi.org/10.3989/gya.2005.v56.i2.122

[3] Ducci, F., Rogatis, A. and Proietti, R. (1997) Protezione delle risorse genetiche di Juglans regia L. Annali dell'Istituto Sperimentale della Selvicoltura, 25, 35-55.

[4] Jay-Allemand, C., Fady, B. and Becquey, J. (1996) Walnut Trees for Woodland Use in Mediterranean Countries: Current Situation and Prospects. FAO Nucis Newsletter, $5,10-13$.

[5] FAOSTAT (2015) Fao Web Page. http://www.fao.org

[6] Blomhoff, R., Carlsen, M.H., Andersen, L.F. and Jacobs, D.R. (2006) Health Benefits of Nuts: Potential Role of Antioxidants. British Journal of Nutrition, 96, S52-S60. https://doi.org/10.1017/BJN20061864

[7] Davis, L., Stonehouse, W., Mukuddem-Petersen, J., van der Westhuizen, F.H., Hanekom, S.M. and Jerling, J.C. (2007) The Effects of High Walnut and Cashew Nut Diets on the Antioxidant Status of Subjects with Metabolic Syndrome. European Journal of Nutrition, 46, 155-164. https://doi.org/10.1007/s00394-007-0647-x

[8] Oliveira, I., Sousa, A., Ferreira, I.C., Bento, A., Estevinho, L. and Pereira, J.A. (2008) Total Phenols, Antioxidant Potential and Antimicrobial Activity of Walnut (Juglans regia L.) Green Husks. Food and Chemical Toxicology, 46, 2326-2331. https://doi.org/10.1016/j.fct.2008.03.017

[9] Proestos, C., Chorianopoulos, N., Nychas, G.J. and Komaitis, M. (2005) RP-HPLC Analysis of the Phenolic Compounds of Plant Extracts. Investigation of Their Antioxidant Capacity and Antimicrobial Activity. Journal of Agricultural and Food Chemistry, 53, 1190-1195. https://doi.org/10.1021/jf040083t

[10] Sousa, A., Ferreira, I.C., Calhelha, R., Andrade, P.B., Valentão, P., Seabra, R. and Pereira, J.A. (2006) Phenolics and Antimicrobial Activity of Traditional Stoned Table Olives “Alcaparra”. Bioorganic \& Medicinal Chemistry, 14, 8533-8538. https://doi.org/10.1016/j.bmc.2006.08.027

[11] Amaral, J.S., Casal, S., Pereira, J.A., Seabra, R.M. and Oliveira, B.P. (2003) Determi- 
nation of Sterol and Fatty Acid Compositions, Oxidative Stability, and Nutritional Value of Six Walnut (Juglans regia L.) Cultivars Grown in Portugal. Journal of Agricultural and Food Chemistry, 51, 7698-7702. https://doi.org/10.1021/jf030451d

[12] Amaral, J.S., Alves, M.R., Seabra, R.M and Oliveira, B.P.P. (2005) Vitamin E Composition of Walnuts (Juglans regia L.): A 3-Year Comparative Study of Different Cultivars. Journal of Agricultural and Food Chemistry, 53, 5467-5472. https://doi.org/10.1021/jf050342u

[13] Qa'dan, F., Thewaini, A.J., Ali, D.A., Afifi, R., Elkhawad, A. and Matalka, K.Z. (2005) The Antimicrobial Activities of Psidium guajava and Juglans regia Leaf Extracts to Acne-Developing Organisms. The American Journal of Chinese Medicine, 33, 197-204. https://doi.org/10.1142/S0192415X05002783

[14] Harper, C.R. and Jacobson, T.A. (2001) The Fats of Life: The Role of Omega-3 Fatty Acids in the Prevention of Coronary Heart Disease. Archives of Internal Medicine, 161, 2185-2192. https://doi.org/10.1001/archinte.161.18.2185

[15] Bucher, H.C., Hengstler, P., Schindler, C. and Meier, G. (2002) N-3 Polyunsaturated Fatty Acids in Coronary Heart Disease: A Meta-Analysis of Randomized Controlled Trials. The American Journal of Medicine, 112, 298-304. https://doi.org/10.1016/S0002-9343(01)01114-7

[16] Abbey, M., Noakes, M., Belling, G.B. and Nestel, P.J. (1994) Partial Replacement of Saturated Fatty Acids with Almonds or Walnuts Lowers Total Plasma Cholesterol and Low-Density-Lipoprotein Cholesterol. The American Journal of Clinical Nutrition, 59, 995-999.

[17] Olez, H. (1971) Marmara Bölgesi Cevizlerinin (Juglans regia L.) Seleksiyon Yoluyla ıslahı Üzerine Araştırmalar. Yalova Bahçe Kültürleri Araştırma Merkezi Dergisi, 4, 1 .

[18] Koyuncu, M. and Aşkın, M.A. (1999) Van Gölü çevresinde yetiştiriciliği yapılan bazı ceviz tiplerinin depolanması üzerine çalışmalar. Turkish Journal of Agriculture and Forestry, 23, 785.

[19] Caglarırmak, N. (2003) Biochemical and Physical Properties of Some Walnut Genotypes (Juglans regia L.). Nahrurg/ Food, 47, 28.

[20] Bligh, E.G. and Dyer, W.J. (1959) A Rapid Method of Total Lipid Extraction and Purification. Canadian Journal of Biochemistry and Physiology, 37, 911-917. https://doi.org/10.1139/y59-099

[21] AOAC (1990) Official Methods of Analysis, 952.03. 15th Edition, Association of Official Analytical Chemists, Washington DC.

[22] Ichihara, K., Shibahara, A., Yamamoto, K. and Nakayama, T. (1996) An Improved Method for Rapid Analysis of the Fatty Acids of Glycerolipids. Lipids, 31, 535-539. https://doi.org/10.1007/BF02522648

[23] Surai, P.F., Noble, R.C. and Speake, B.K. (1996) Tissue-Specific Differences in Antioxidant Distribution and Susceptibility to Lipid Peroxidation during Development of the Chick Embryo. Biochimica et Biophysica Acta (BBA)-Lipids and Lipid Metabolism, 1304, 1-10. https://doi.org/10.1016/S0005-2760(96)00099-9

[24] Surai, P.F. (2000) Effect of Selenium and Vitamin E Content of the Maternal Diet on the Antioxidant System of the Yolk and the Developing Chick. British Poultry Science, 41, 235-243. https://doi.org/10.1080/713654909

[25] Spanos, G.A. and Wrolstad, R.E. (1990) Influence of Processing and Storage on the Phenolic Composition of Thompson Seedless Grape Juice. Journal of Agricultural and Food Chemistry, 38, 1565-1571. https://doi.org/10.1021/jf00097a030 
[26] Lavedrine, F., Ravel, A., Poupard, A. and Alary, J. (1997) Effect of Geographic Origin, Variety and Storage on Tocopherol Concentrations in Walnuts by HPLC. Food Chemistry, 58, 135-140. https://doi.org/10.1016/S0308-8146(96)00232-4

[27] Savage, G.P., Dutta, P.C. and McNeil, D.L. (1999) Fatty Acid and Tocopherol Contents and Oxidative Stability of Walnut Oils. Journal of the American Oil Chemists' Society, 76, 1059-1063.

[28] Jiang, Q., Christen, S., Shigenaga, M.K. and Ames, B.N. (2001) $\gamma$-Tocopherol, the Major Form of Vitamin E in the US Diet, Deserves More Attention. The American Journal of Clinical Nutrition, 74, 714-722.

[29] Anderson, K.J., Teuber S.S., Gobeille, A., Cremin, P., Waterhouse, A.L. and Steinberg, F.M. (2001) Walnut Polyphenolics Inhibit in Vitro Human Plasma and LDL Oxidation. Journal of Nutrition, 131, 2837-2842.

[30] Wu, X.L., Beecher, G.R., Holden, J.M., Haytowitz, D.B., Gebhardt, S.E. and Prior, R.L. (2004) Lipophilic and Hydrophilic Antioxidant Capacities of Common Foods in the United States. Journal of Agricultural and Food Chemistry, 52, 4026-4037. https://doi.org/10.1021/jf049696w

[31] Abe, L.T., Lajolo, F.M. and Genovese, M.I. (2010) Comparison of Phenol Content and Antioxidant Capacity of Nuts. Ciência e Tecnologia de Alimentos, Campinas, 30, 254-259. https://doi.org/10.1590/S0101-20612010000500038

[32] Kornsteiner, M., Wagner, K.H. and Elmadfa, I. (2006) Tocopherols and Total Phenolics in 10 Different Nut Types. Food Chemistry, 98, 381-387.

https://doi.org/10.1016/j.foodchem.2005.07.033

[33] Mitrovic, M., Stanisavljevic, M. and Gavrilovic-Danjanovic, J. (1995) Biochemical Composition of Fruits of Some Important Walnut Cultivars and Selections. III International Walnut Congress, 442, 205-208.

[34] Beceanu, D., Chira, A. and Pasca, I. (2000) Fructe, legume siflori. Metode de prelungire si păstrare în stare proaspătă. Conserve de legume si fructe, Editura M.A.S.T. Bucuresti.

[35] Dogan, M. and Akgul, A. (2005) Fatty Acid Composition of Some Walnut (Juglans regia L.) Cultivars from East Anatolia. Grasas y Aceites, 56, 328-331. https://doi.org/10.3989/gya.2005.v56.i4.101

[36] Popa, V.M., Hadaruga, N., Gruia, A., Raba, D.N., Moldovan, C. and Poiana, A.M. (2011) Gas Chromatography from the GC-MS Analysis for the Walnut Grown in Romania. Journal of Agroalimentary Processes and Technologies, 17, 261-265.

[37] Beyazit, S. and Sumbul, A. (2012) Determination of Fruit Quality and Fatty Acid Composition of Turkish Walnut (Juglans regia) Cultivars and Genotypes Grown in Subtropical Climate of Eastern Mediterranean Region. International Journal of Agriculture \& Biology, 14, 419.

[38] Zwarts, L., Savage, G.P. and McNeil, D.L. (1999) Fatty Acid Content of New Zealand-Grown Walnuts (Juglans regia L.). International Journal of Food Sciences and Nutrition, 50, 189-194. https://doi.org/10.1080/096374899101229

[39] Pereira, J.A., Oliveira, I., Sousa, A., Ferreira, I.C., Bento, A. and Estevinho, L. (2008) Bioactive Properties and Chemical Composition of Six Walnut (Juglans regia L.) Cultivars. Food and Chemical Toxicology, 46, 2103-2111. https://doi.org/10.1016/j.fct.2008.02.002

[40] Maguire, L.S., O’Sullivan, S.M., Galvin, K., O’Connor, T.P. and O’Brien, N.M. (2004) Fatty Acid Profile, Tocopherol, Squalene and Phytosterol Content of Walnuts, Almonds, Peanuts, Hazelnuts and the Macadamia Nut. International Journal of Food Sciences and Nutrition, 55, 171-178. 
https://doi.org/10.1080/09637480410001725175

[41] Li, L., Tsao, R., Yang, R., Kramer, J.K. and Hernandez, M. (2007) Fatty Acid Profiles, Tocopherol Contents, and Antioxidant Activities of Heartnut (Juglans ailanthifolia var. cordiformis) and Persian Walnut (Juglans regia L.). Journal of Agricultural and Food Chemistry, 55, 1164-1169. https://doi.org/10.1021/jf062322d 